\title{
The Protective Effect of Methanol Extract of Rauvolfia vomitoria against the Clastogenicity and Hepatotoxicity of Sodium Arsenite in Mice
}

\author{
Kazeem A. Akinwumi ${ }^{1, *}$, Osifeso O. Olabode ${ }^{2,3}$ and Adedoja A. Wakeel ${ }^{4}$ \\ ${ }^{1}$ Department of Chemical and Food Sciences, Bells University of Technology, Ota, Ogun State, Nigeria \\ ${ }^{2}$ Department of Sciences Laboratory Technology, Moshood Abiola Polytechnic, Abeokuta, Nigeria \\ ${ }^{3}$ Department of Environmental Management and Toxicology Universidad Aldersgate, Solano Nuevva \\ Vizcaya, Philippines \\ ${ }^{4}$ Department of Public Health City University of New York, New York, USA
}

\begin{abstract}
Exposure to arsenic is a public health concern and many strategies are being employed to counter arsenic intoxication. Here, we investigated the effect of methanol leaf extracts of Rauvolfia vomitoria (MRV) on mice exposed to sodium arsenite (SA) using micronucleus assay and monitoring the activities of $\gamma$-glutamyltransferase $(\gamma-G T)$, alkaline phosphate (ALP), aspartate aminotransferase (AST) and alanine-aminotransferase (ALT) in the plasma. In addition, pathological examination of the liver of test and control mice was carried out. Test mice were exposed to 1300,650 and $325 \mathrm{mg} / \mathrm{kg}$ body weight of MRV for seven consecutive days before injection (i.p.) with $1 \mathrm{mg} / \mathrm{kg}$ body weight of SA on the seventh day. Negative control mice were given distilled water, while the positive control animals were injected with 1 $\mathrm{mg} / \mathrm{kg}$ body weight of SA twenty hours before the experiment was terminated on the eighth day. The SA significantly $(p<$ 0.05 ) increased the frequency of micronucleated polychromatic erythrocyte (mPCE) and the activities of $y$-GT, ALP, AST and ALT when compared to the negative control. Mice treated with SA showed portal inflammation and hepatocyte necrosis. Pretreatment with MRV significantly $(p<0.05)$ reduced the biochemical parameters except ALT that was increased in animals treated with SA and $1300 \mathrm{mg} / \mathrm{kg}$ body weight MRV. Histopathological changes induced by SA were prevented by 650 and $325 \mathrm{mg} / \mathrm{kg}$ body weight MRV. This suggests that methanol extract of Rauvolfia vomitoria offers some degree of chemo-protection against SA induced clastogenicity and liver damage at lower doses.
\end{abstract}

Keywords: Arsenic, medicinal plant, micronucleated polychromatic erythrocytes, $\mathrm{Y}$-glutamyl transferase, alkaline phosphatase, alanine amino transferase and aspartate amino transferase.

\section{INTRODUCTION}

Chronic exposure to arsenic in water, food, air, soil and drug is a public health concern. Several diseases and health hazards have been associated with exposure to the heavy metal especially through water. Ischemic heart diseases, diabetes, skin diseases, neurogenic problems, teratogenicity, and various cancers have all been reported in people living in arsenic endemic areas of the world [1-4]. In vivo experiments have also given credence to the potential cancer causing ability of arsenic compounds [5]. Of all the arsenic compounds, arsenite (As III compounds) have been reported to have the greatest toxic effects [6]. Arsenites are genotoxic and some of the mechanisms of arsenite induced carcinogenesis occur via gene amplification, blocking of the DNA repair process, induction of chromosomal aberration and micronuclei formation [7-8].

Several intervention strategies have been proposed and trials done to prevent or at least alleviate the

*Address correspondence to this author at the Bells Drive Benja Village, P.M.B. 1015, Ota, Ogun State Nigeria; Tel: +234-803-563-9816;

E-mail: qaakinwumi@yahoo.co.uk suffering caused by arsenic intoxication [9]. Safe drinking water and consumption of foods rich in substances that protect against arsenic toxicity may play a pivotal role in solving arsenic related health problems [9-11]. The use of medicinal plants and their constituents have also been identified as a potential means of attenuating the health effects caused by chronic arsenic exposure [12-15]. Consequently therefore, researches are directed towards identifying medicinal herbs with chemopreventive role against arsenite toxicity and assessing them for their efficacy.

Rauvolfia vomitoria is a medicinal plant that is widely distributed in the humid tropical secondary and low land forests of Africa [16]. It belongs to the family Apocynaceae and grows to a height of about $15 \mathrm{~m}$. Across the coast of West Africa, it is planted as ornamental tree, shade provider for plant like cocoa, support for vanilla and for live fencing [17]. The plant has found wide applications in traditional medicine across the world. Traditional medicine practitioners in Nigeria and other parts of Africa use different parts of the plant in treating fever, general weakness, intestinal diseases, liver problems, mental illness, haemorrhoids, hypertension, snakebite and cholera [17-22]. 
Decoctions of the leaves have powerful emetic and anti-swelling effect [23]. In addition, its tissue lipid lowering-effect, antipyretic, analgesic, haematinic, aphrodisiac, purgative, dysenteric, abortive, insecticidal, anticonvulsant properties have all been documented [17-18, 24]. Extract from the plant have also been reported to inhibit the growth of bacterial, viral, fungal and parasitic pathogens [25-26]. However to date, no information exists in literature about the effect of consumption of Rauvolfia vomitoria against arsenic intoxication. Therefore, the present study was undertaken to investigate the effect of pretreatment of mice with methanol extract of Rauvolfia vomitoria on the clastogenic and hepatotoxic potential of sodium arsenite.

\section{MATERIALS AND METHODS}

\subsection{Chemical Reagents}

Sodium arsenite $\left(\mathrm{Na}_{2} \mathrm{AsO}_{2}\right)$ [Mol wt. 129.9, As 57.6 \% (As No. 778 4-46-5)] from Sigma Chemical Co., St. Louis, MO was dissolved in distilled water and administered at a dose of $1.0 \mathrm{mg} / \mathrm{kg}$ body weight. All other chemicals used were of analytical grade and were also obtained from Sigma chemical Co. Louis Mo. USA. Gamma-Glutamyl Transferase $(\gamma-\mathrm{GT})$, Alkaline Phosphatase (ALP), Alanine aminotransferase (ALT) and Aspartate amino transfearse (AST) kits were obtained from Randox Laboratories Ltd, United Kingdom.

\subsection{Plant Extract}

Fresh leaves of Rauvolfia vomitoria were collected from the Botanical Garden, University of Ibadan, Ibadan. The leaves were identified by Mr. O.S. Shasanya and Osiyemi O.A. at the herbarium in the Forestry Research Institute of Nigeria (FRIN), Ibadan and voucher specimen deposited at the same herbarium (Voucher No: FHI108901). The fresh leaves were air dried for 8 weeks at room temperature, after which they were completely dried in a solar drier at 40 ${ }^{0} \mathrm{C}$. The dried leaves were then milled in a hammermiller with mesh size $0.27 \mu \mathrm{m}$. The powder obtained was soaked for twenty hours in $70 \%$ methanol. The suspension obtained was filtered and concentrated with a rotary evaporator and subsequently, evaporated to constant weight in an oven at $40{ }^{\circ} \mathrm{C}$. The percentage yield was $9.7 \%$. A dosage of 1300,650 and $325 \mathrm{mg} / \mathrm{kg}$ body weight corresponding to $1 / 20$ th, $1 / 10$ th and $1 / 30$ th of the LD 50 of Rauvolfia vomitoria (Amole et al. 1993) was dissolved in distilled water and injected intraperitoneally into test animals.

\subsection{Experimental Animals}

Twenty-five male wistar albino mice approximately 8-10 weeks old with average weight of $20 \mathrm{~g}$ obtained from the Animal House of the University of Lagos Teaching Hospital (LUTH), Idi-Araba, Lagos State, Nigeria were used for the experiment. They were housed five per cage with wood shaven bedding in polypropylene cages under standard environmental conditions at the Experimental Animal House, Department of Chemical and Food Sciences, Bells University of Technology, Ota, Ogun State, Nigeria. They were fed with mice pellet containing at least $20 \%$ protein, $3.5 \%$ fat, $9.0 \%$ fibre, $1.2 \%$ calcium, $0.7 \%$ phosphorus, vitamin, mineral per mix, antioxidant, antibiotics, carbohydrates etc from God First Feed Mill, Bodija, Ibadan, Nigeria and water adlibitum. A period of two weeks was allowed for the animals to acclimatize before the commencement of the experiment.

\subsection{Experimental Protocol}

The experimental mice were randomly divided into five treatment groups of five animals each.

Mice in group I (negative control) were given distilled water and normal diet throughout the experiment. Mice in group II were placed on normal diet for seven consecutive days and injected intraperitoneally with $1.0 \mathrm{mg} / \mathrm{kg}$ body weight of sodium arsenite (SA) on the seventh day. Mice in groups III, IV and $V$ were pretreated with 1300,650 and $325 \mathrm{mg} / \mathrm{kg}$ body weight of methanol extract of Rauvolfia vomitoria (MRV) respectively for seven consecutive days and on the seventh day, injected $1.0 \mathrm{mg} / \mathrm{kg}$ bodyweight of SA. The mice were sacrificed by cervical dislocation twentyfour hours after the last treatments were administered. The bone marrow from femurs of each animal were harvested for micronucleus assay, while blood was collected via cardiac puncture and plasma prepared for enzyme analysis. The liver of each mouse was also collected for pathological examination.

\subsection{Micronucleus Assay}

The micronucleus assay was performed according to the method of Schmid [27]. Essentially, the femur of each mouse was freed and stripped clean of muscles. The iliac end of the femur was carefully shortened until a small opening to the marrow became visible. Subsequently, $1 \mathrm{ml}$ syringe with Fetal Bovine Serum 
(FBS) was passed through the opening to flush out the bone marrow cells. This was thoroughly mixed and then transferred into different ependorff tubes. The mixture was then centrifuged at $2000 \mathrm{rpm}$ for 5 minutes. The pellet obtained was re-suspended in FBS and centrifuged again at $2000 \mathrm{rpm}$ for 5 minutes. Thereafter, $0.5 \mathrm{ml}$ of FBS was added to the pellet in the ependorff tubes and mixed thoroughly. The homogenous suspension obtained was dropped on a pre-cleaned pre-labelled slide and smeared. The slides were air dried and fixed in absolute methanol for two minutes and further air dried to remove the methanol. The dried slides were stained according to the method of Adler [28]. Briefly, the slides were placed vertically in a coupling jar containing $0.4 \%$ of May-Grunwald stain for 3-4 minutes and immediately transferred into another coupling jar containing 1:1 May-Grunwald and distilled water for another 3-4 minutes. The slides were removed and rinsed in distilled water and allowed to dry. The dried slides were then stained in $5 \%$ Giemsa stain that was initially dissolved in $0.01 \mathrm{M}$ phosphate buffer $\mathrm{pH}$ 6.8. They were thereafter rinsed in distilled water, air dried, mounted in DPX (BDH) and covered with cover glass smeared with xylene. The stained and mounted slides were coded and scored using an Olympus XSZ 107 BN microscope for the presence of micronucleated polychromatic erythrocytes.

\subsection{Enzyme Assay}

The blood samples collected were transferred into pre-labeled heparinized bottles and centrifuged at $2,000 \mathrm{~g}$ for 20 minutes. The clear supernatants obtained were decanted and used immediately for the determination of plasma liver function enzymes activities.

Gamma-glutamyl transferase ( $\gamma$-GT) activity was assayed in the plasma using reconstituted $\gamma$-GT reagent kits following the method of Szasz [29]. Essentially, $0.5 \mathrm{ml}$ of the plasma was mixed with 0.05 $\mathrm{ml}$ of the reconstituted reagent. The absorbance of the mixture was read at $405 \mathrm{~nm}$ four times with a minute interval between the readings. The mean changes in absorbance per minute were then recorded.

Alkaline phosphatase (ALP) activity was also assayed in the plasma using the reconstituted ALP reagent. Essentially, $2.5 \mathrm{ml}$ of the reagent at $25{ }^{\circ} \mathrm{C}$ was mixed with $0.05 \mathrm{ml}$ of the sample. The mixture was then incubated at $25{ }^{\circ} \mathrm{C}$ and the absorbance of the mixture was read twice at a minute interval at $405 \mathrm{~nm}$. The change in absorbance per minute was then estimated. The levels of ALT and AST activity in the plasma was determined using kits (Randox Laboratories Ltd, UK) and following the manufacturer's direction. Briefly, $0.1 \mathrm{ml}$ of the sample was mixed with $5 \mathrm{ml}$ of Solution 1(Buffer; Phosphate buffer, L- Alanine or L- Aspartate and $\alpha$-Oxoglutarate) and incubated for exactly 30 minutes at $37{ }^{\circ} \mathrm{C}$. Thereafter, $0.5 \mathrm{ml}$ of Solution 2 (2,4-dinitrophenylhydrazine) was added, mixed and allowed to stand for exactly 20 minutes at 20-25 ${ }^{\circ} \mathrm{C}$. Subsequently, $5.0 \mathrm{ml}$ of $\mathrm{NaOH}$ was added and the absorbance of the sample was read against the reagent blank at $546 \mathrm{~nm}$ after 5 minutes.

\subsection{Histopathology Analysis}

Pathological changes in the liver were examined following the method of Germanó et al. [30]. The liver sections were fixed in $4 \% \mathrm{p}$ - formaldehyde and washed in phosphate buffer $\mathrm{pH} 7.4$ at $4{ }^{\circ} \mathrm{C}$ for 12 hours. After dehydration, the tissue was embedded in paraffin, cut into $5 \mu \mathrm{m}$ sections, stained with haematoxylin-eosin dye and finally observed under an Olympus BX 41 photomicroscope.

\subsection{Statistical Analysis}

Data were expressed as Mean \pm SE. One-way ANOVA was used to analyze data, while intergroup significant difference was determined by the Duncan Multiple Range Test. Differences were considered significant if $p<0.05$.

\section{RESULT}

The effect of MRV on SA-induced micronuclei formation is shown in Figure 1. The induction of the frequency of micronuclei formation in polychromatic erythrocytes was increased significantly $(p<0.05)$ by 8.39 fold in the sodium arsenite (SA) treated mice when compared to the negative control (Figure 1). The SA induced micronuclei formation was however, reduced significantly $(p<0.05) 2.42,3.23,5.81$ and folds respectively by pretreatment with 325,650 and $1300 \mathrm{mg} / \mathrm{kg}$ methanol extract of Rauvolfia vomitoria (MRV).

The effect of MRV on SA-induced increase in gamma glutamyl transferase $(\gamma-\mathrm{GT})$ is shown in Figure 2. The $\mathrm{SA}$ administration significantly $(p<0.05)$ increased plasma activity of $\gamma$-GT by about $59.53 \%$ in the plasma when compared with the negative control. However, pretreatment with 325, 650 and $1300 \mathrm{mg} / \mathrm{kg}$ MRV significantly $(p<0.05)$ reduced the plasma 


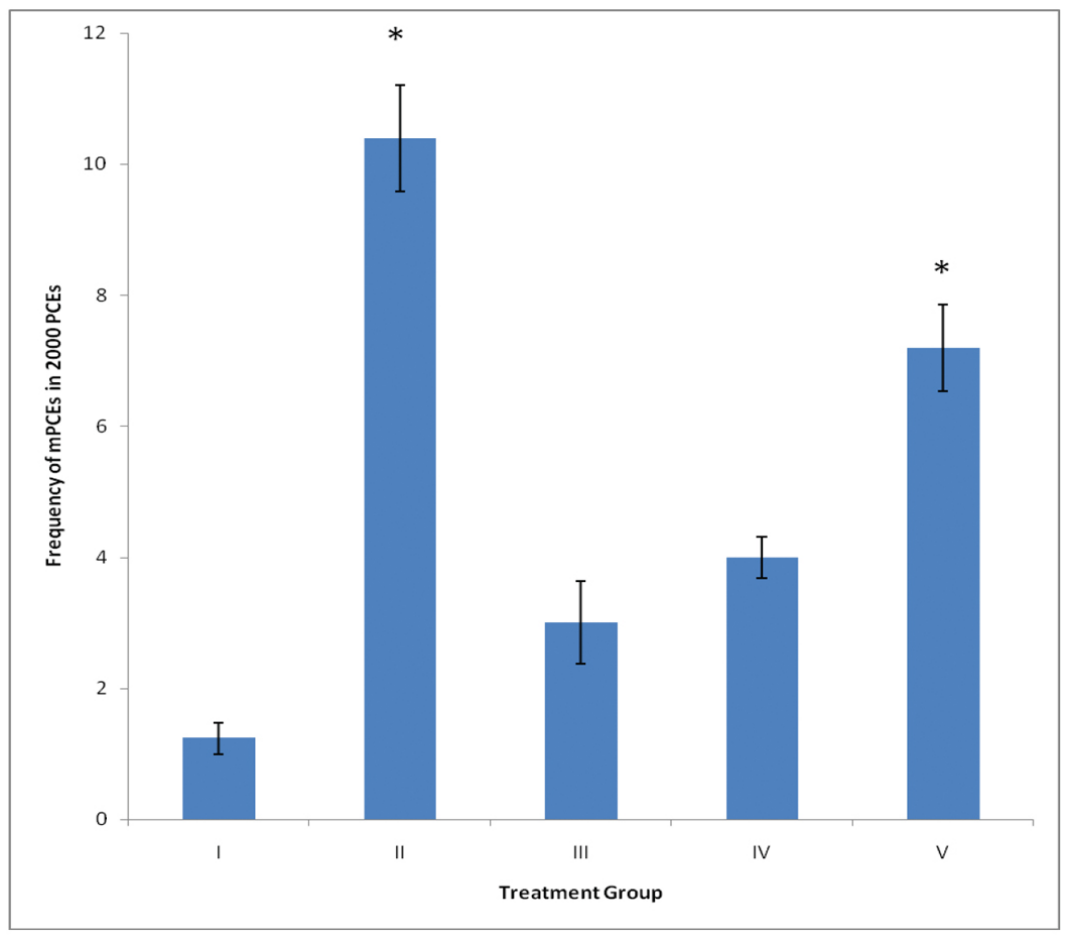

Figure 1: The protective effect of methanol extract of Rauvolfia vomitoria on the frequency of micronucleated polychromatic erythrocytes induced by sodium arsenite in mice.

*Significantly different $(p<0.05)$ from the control group.

Legend: I= Distilled water; II= Sodium Arsenite (SA); III= $325 \mathrm{mg} / \mathrm{kg}$ body weight methanol extract of Rauvolfia vomitoria (MRV) + $S A ; I V=650 \mathrm{mg} / \mathrm{kg}$ body weight $R V+S A ; V=1300 \mathrm{mg} / \mathrm{kg}$ body weight $R V+S A$.

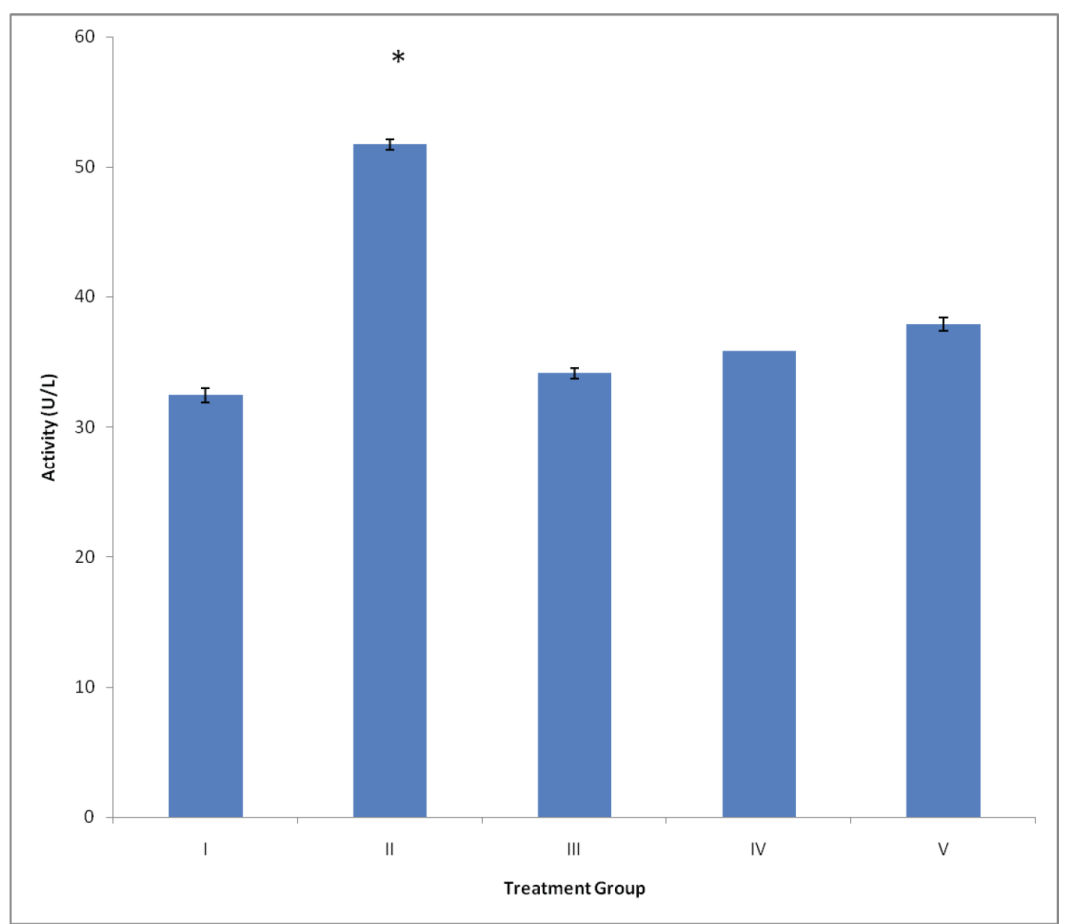

Figure 2: The protective effect of methanol extract of Rauvolfia vomitoria against the increased activity of gamma glutamyl transferase induced by sodium arsenite in mice. Values are presented as means $\pm \mathrm{SE}$.

*Significantly different $(p<0.05)$ from control group.

Legend: I= Distilled water; II= Sodium Arsenite (SA); III= $325 \mathrm{mg} / \mathrm{kg}$ body weight methanol extract of Rauvolfia vomitoria (MRV) + $\mathrm{SA} ; \mathrm{IV}=650 \mathrm{mg} / \mathrm{kg}$ body weight $\mathrm{RV}+\mathrm{SA} ; \mathrm{V}=1300 \mathrm{mg} / \mathrm{kg}$ body weight $\mathrm{RV}+\mathrm{SA}$. 


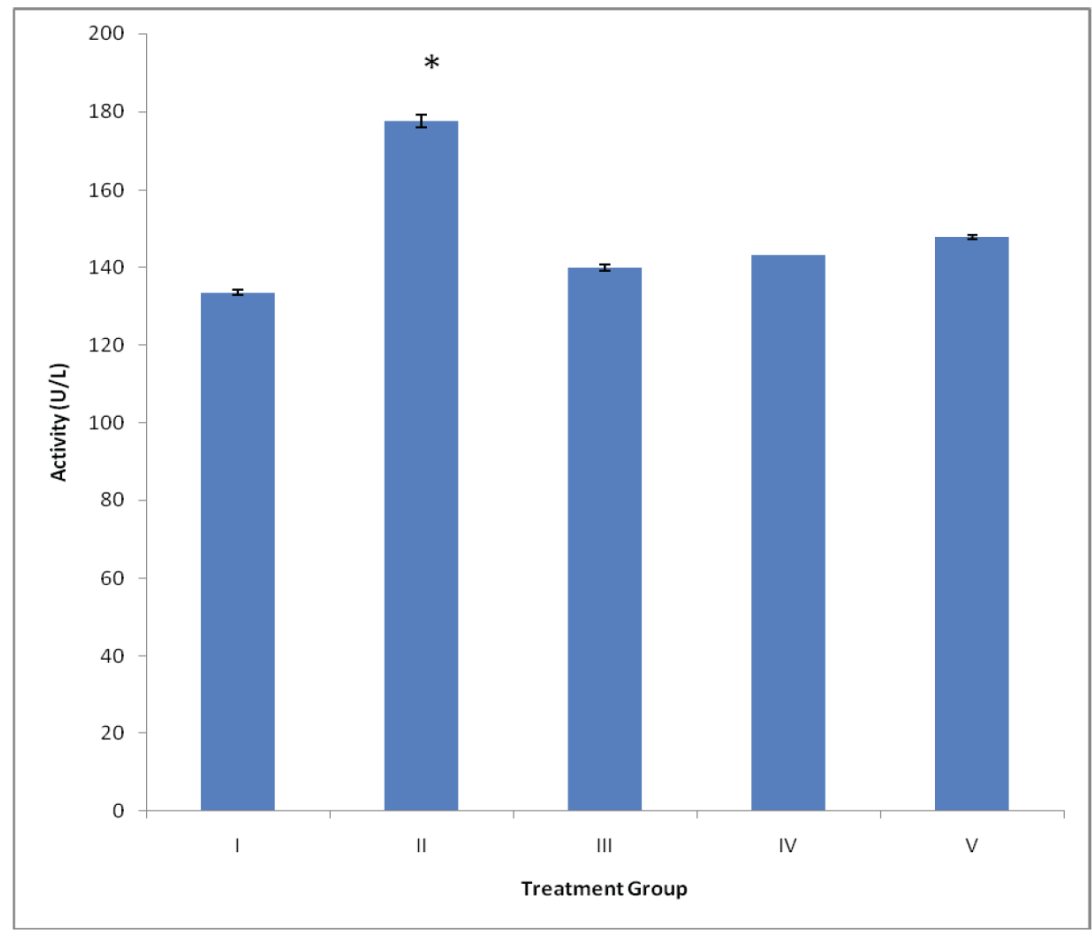

Figure 3: The protective effect of methanol extract of Rauvolfia vomitoria against the increased activity of alkaline phosphatase induced by sodium arsenite in mice. Values are presented as means $\pm \mathrm{SE}$.

*Significantly different $(p<0.05)$ from control group.

Legend: I= Distilled water; II= Sodium Arsenite (SA); III= $325 \mathrm{mg} / \mathrm{kg}$ body weight methanol extract of Rauvolfia vomitoria (MRV) + $\mathrm{SA} ; \mathrm{IV}=650 \mathrm{mg} / \mathrm{kg}$ body weight $\mathrm{RV}+\mathrm{SA} ; \mathrm{V}=1300 \mathrm{mg} / \mathrm{kg}$ body weight $\mathrm{RV}+\mathrm{SA}$.

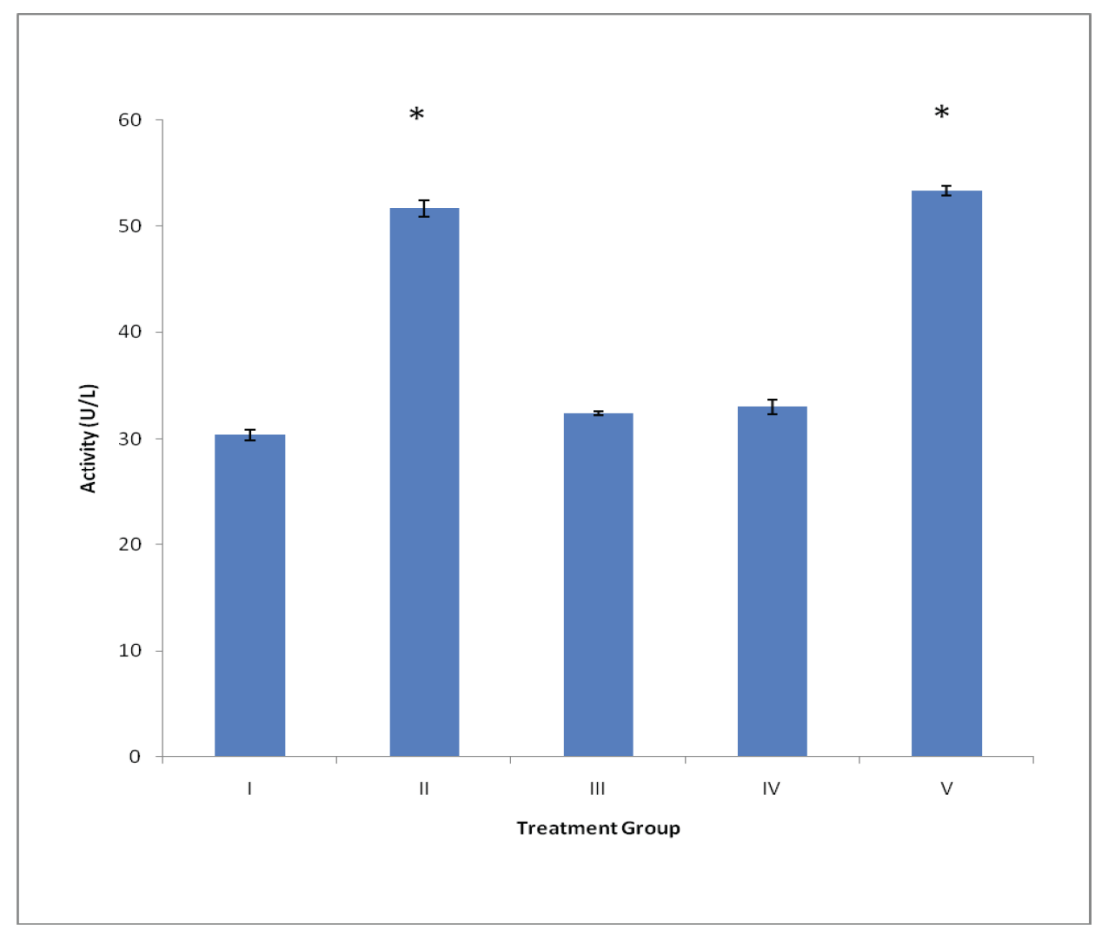

Figure 4: The protective effect of methanol extract of Rauvolfia vomitoria against the increased activity of alanine amino transferase induced by sodium arsenite in mice. Values are presented as means \pm SE.

* Significantly different $(p<0.05)$ from control group.

Legend: I= Distilled water; II= Sodium Arsenite (SA); III = $325 \mathrm{mg} / \mathrm{kg}$ body weight methanol extract of Rauvolfia vomitoria (MRV)

+ SA; IV = $650 \mathrm{mg} / \mathrm{kg}$ body weight $\mathrm{RV}+\mathrm{SA} ; \mathrm{V}=1300 \mathrm{mg} / \mathrm{kg}$ body weight $\mathrm{RV}+\mathrm{SA}$. 


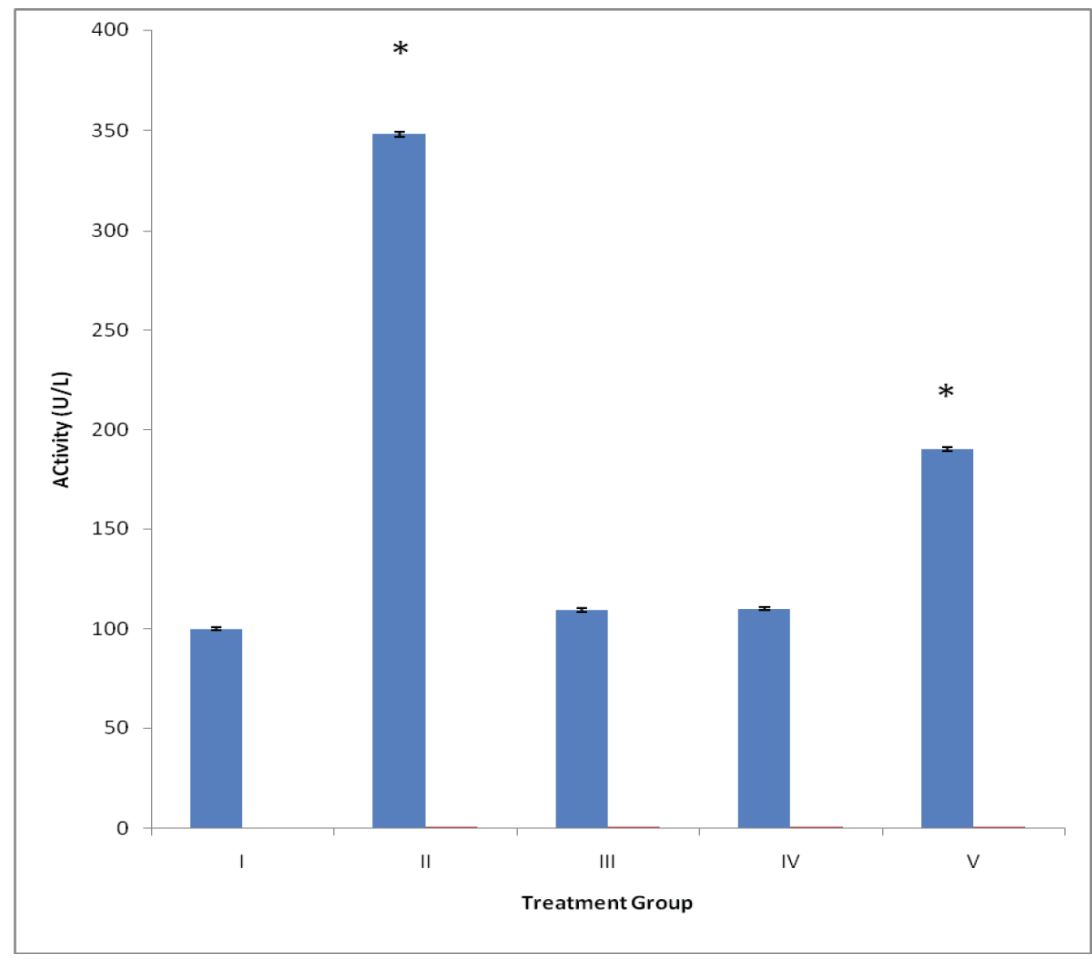

Figure 5: The protective effect of methanol extract of Rauvolfia vomitoria against the increased activity of aspartate amino transferase induced by sodium arsenite in mice. Values are presented as means $\pm \mathrm{SE}$.

* Significantly different $(p<0.05)$ from control group.

Legend: I= Distilled water; II= Sodium Arsenite (SA); III= $325 \mathrm{mg} / \mathrm{kg}$ body weight methanol extract of Rauvolfia vomitoria (MRV) + $\mathrm{SA} ; \mathrm{IV}=650 \mathrm{mg} / \mathrm{kg}$ body weight $\mathrm{RV}+\mathrm{SA} ; \mathrm{V}=1300 \mathrm{mg} / \mathrm{kg}$ body weight $\mathrm{RV}+\mathrm{SA}$.

activity of $\gamma$-GT to $5.18, \quad 10.43$ and $16.72 \%$ respectively.

The effect of MRV on SA-induced increase in plasma alkaline phosphatase (ALP) is shown in Figure 3. The ALP activity was increased significantly $(p<$ $0.05)$ to $33.13 \%$ in mice treated with $S A$ when compared to the negative control. Conversely, pretreatment with 1300, 650 and $325 \mathrm{mg} / \mathrm{kg}$ MRV before exposure to SA significantly reduced the hike in ALP activity to $4.82,7.23$ and $10.82 \%$ respectively.

The effect of MRV on SA-induced increase in alanine amino transferase (ALT) is shown in Figure 4. Treatment of mice with SA led to a $70.20 \%$ significant increase $(p<0.05)$ in the activity of ALT when compared with the control. This was significantly $(p<$ 0.05 ) reduced to $6.58 \%$ and $8.55 \%$ in the mice pretreated with $325 \mathrm{mg} / \mathrm{kg}$ and $650 \mathrm{mg} / \mathrm{kg}$ of MRV respectively. However, the $1300 \mathrm{mg} / \mathrm{kg}$ dose increased the ALT activity by $75.53 \%$ when compared with the control.

The effect of MRV on SA-induced increase in plasma aspartate aminotransferase (AST) is shown in Figure 5. When compared to the negative control, plasma aspartate amino transferase (AST) activity was found to be elevated significantly $(p<0.05)$ to $248 \%$ in mice treated with SA. In contrast, pretreatment with 325,650 and $1300 \mathrm{mg} / \mathrm{kg}$ MRV before exposure to SA significantly reduced AST to about $9.34,10$ and $90 \%$, respectively.

The effect of MRV on SA-induced hepatic injury is shown in Figure 6A-E. Unlike the negative control that showed normal liver architecture, administration of SA led to the disorientation of normal hepatocytes. Severe necrosis and portal inflammation were observed in the liver of mice given SA. The liver of mice pretreated with $1300 \mathrm{mg} / \mathrm{kg}$ body weight of MRV prior to arsenic intoxication showed mild sinusoidal congestion, while the lower doses of the extract kept the organ similar to that of the control.

\section{DISCUSSION}

Arsenic is a common environmental pollutant and toxicant to which millions of people worldwide are chronically exposed to through consumption of contaminated drinking water. Chronic exposure to arsenic has been associated with increased risk of several cancers, including lung, bladder, liver, and skin. 

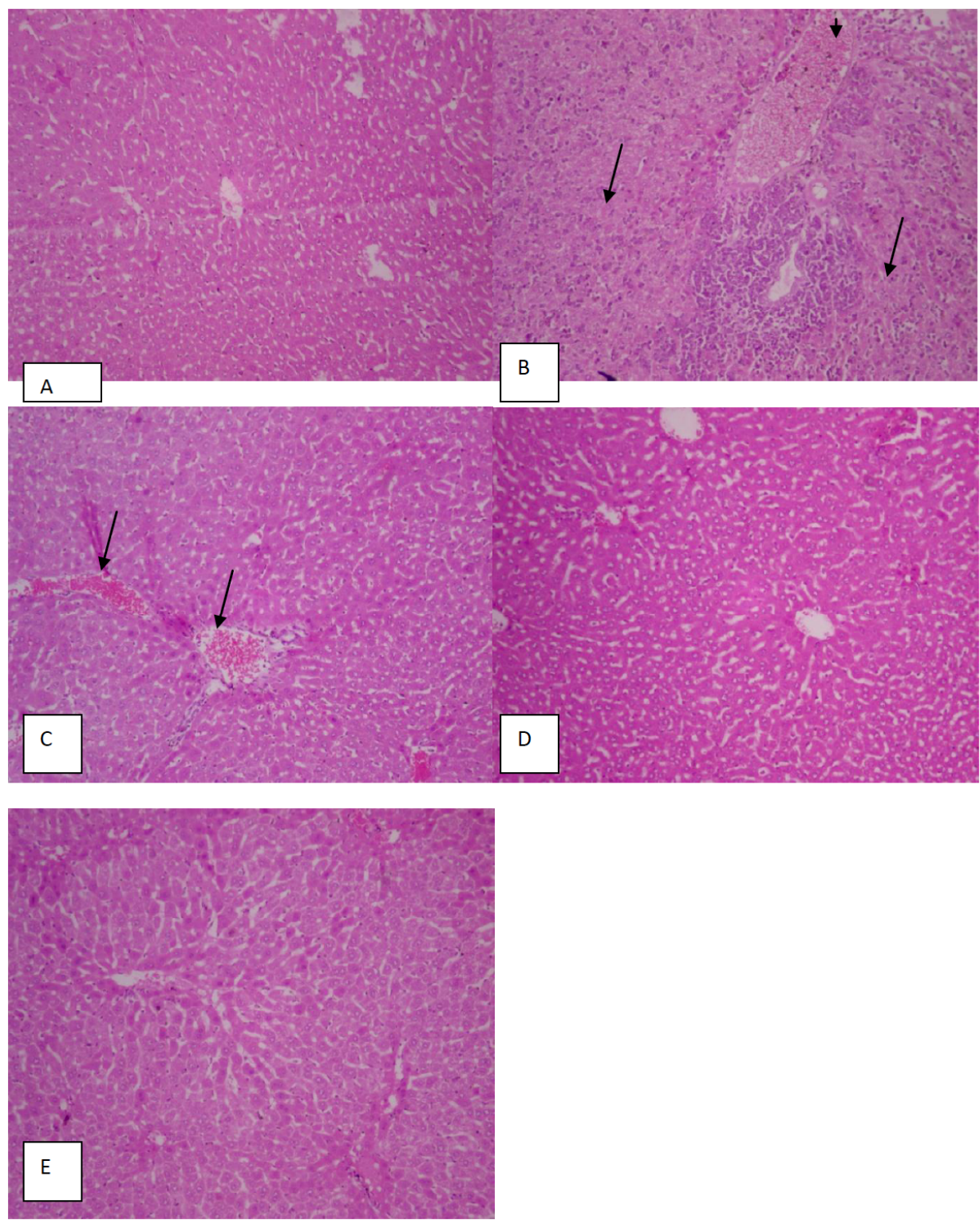

Figure 6: photomicrographs of liver sections showing histopathological changes in liver after sodium arsenite intoxication and prevention by the treatment with methanol extract of Rauvolfia vomitoria (RV) (hematoxylin and eosin X 100). (A) Control mice showing normal hepatocytes. (B) Mice treated with SA alone showing portal inflammation (arrow head) and hepatocyte necrosis (arrow) (C) Mice pretreated with $1300 \mathrm{mg} / \mathrm{kg}$ body weight of RV before SA administration showing mild sinusoidal congestion (arrow). (D \& E) Mice fed 650 and $325 \mathrm{mg} / \mathrm{kg}$ body weight of $R V$ extract then SA showing normal hepatocyte structure.

On the other hand, phytochemicals in diet and medicinal plants markedly influence or alter the adverse effects of arsenic intoxication. In the present study, we examined the protective role of methanol extract of Rauvolfia vomitoria (MRV) against sodium arsenite (SA) induced bone micronuclei formation and hepatotoxicity in mice.

The micronucleus assay is a routine test for the evaluation of acute in vivo geneotoxic effect of chemicals. It is one of the most sensitive and reliable tests for the estimation of clastogenicity or carcinogenic potentials of chemicals [31]. The assay was therefore employed as a marker of clastogenicity in the present study. In concert with studies in our laboratory and that of others [32-34], SA significantly increased $(p<0.05)$ the frequency of induction of micronucleated polychromatic erythrocytes (mPCES) in bone marrow cells when compared with the negative control. This observation in SA treated group is an indication of clastogenic potential of SA. The exact mechanism of the induction of micronuclei by $S A$ is not well established. However, SA is bioactivated to its methlyated forms, dimethyl arsinic acid DMA (III) and monomethyl arsinic acid MMA (III), which have been shown to be genotoxic [35-36]. Similarly, free radicals 
and reactive oxygen species produced during metabolic processing of arsenical compounds [37-39] may bind to DNA causing DNA single-strand breakage and DNA-protein cross-link leading to chromosomal breaks [40]. These radicals and metabolites may also interfere with spindle fiber formation. Both mechanisms are important in the etiology of micronuclei formation by environmental toxicant and clastogens [40-42]. Conversely, the three doses of MRV used in the present study exhibited certain degree of protection against SA induced clastogenicity in polychromatic erythrocytes as evidenced by the inverse dose reduction in the degree of micronucleated PCEs in the animals pretreated with the three doses of the extract and SA. Infact, the $325 \mathrm{mg} / \mathrm{kg}$ body weight dose brought down the degree of mPCEs almost to that observed in the negative control group under our experimental condition. This may not only be suggestive of the beneficial influence of MRV on SA exposure or intoxication, but its clastogenicity as well as carcinogenicity. This observation may be due to the anticancer, antioxidant and free radical scavengers present in MRV [18, 43-44]. Also, ß-carboline alkaloid, alstonine found in the root bark extract of RV has been reported to reduce tumor cell growth in mice inoculated with YC8 lymphoma cells or Ehrlich ascitic cells [45]. Similarly, it was recently shown that extract of Rauvolfia vomitoria effectively inhibit cell growth in the human prostate cancer cell line, LNCaP, in both cell culture and in vivo tumor xenograft experimental systems by suppressing growth and cell cycle progression [18]. The most highly modified gene following treatment with the Rauvolfia vomitoria was shown to be GADD153, which is known to be induced by genotoxic stress and encodes for proteins with antiproliferative activity [46-47].

Elevation of $\gamma$-GT, ALP, AST and ALT in the serum has critical effects and generally considered as an indicator of organ dysfunction. Cell injury to certain organs like liver, kidney and heart leads to their release into the blood stream. Enhancement of plasma $\gamma$-GT activity, a sensitive marker of hepatocyte injury in this study may indicate a nonspecific alteration in the plasma membrane integrity and permeability by SA. Similarly, the elevated $\gamma$-GT activity observed in this study may result from an increase in the rate of synthesis of $\gamma$-GT and leakage of the enzyme into the blood from the liver. Elevation of $\gamma$-GT activity is also associated with oxidative stress and genotoxicity [4849]. Therefore, the elevation of $\gamma$-GT activity in the present study may not only be an indication of hepatotoxicity, but that of oxidative stress and genotoxicity in the animals exposed to SA. However, it is interesting to observe that all the three doses of MRV significantly $(p<0.05)$ reduced the SA induced elevation of $\gamma$-GT activity in the plasma of animal pretreated with MRV. Though the three doses of MRV afforded protection against SA, pretreatment with the $325 \mathrm{mg} / \mathrm{kg}$ body weight was most effective under our experimental condition. Plasma ALP activity were observed to follow the same pattern as that of $\gamma$-GT. Although, we have earlier reported elevation in the plasma ALP of mice fed SA [50], reduction in the activity of the enzyme in the pretreated animals may be due to the ameliorative effect of MRV.

Alanine aminotansferase (ALT) and aspartate aminotansferase (AST) play a crucial role in transamination reactions and are used as potential biomarkers to indicate hepatoxicty and cellular damage. The ALT and AST are cytoplasmic in nature, but upon liver injury these enzymes enter into the circulatory system due to altered permeability of membrane [51-52]. In the present study, treatment with SA was found to cause a significant $(p<0.05)$ increase in ALT and AST activities. Our earlier study in rat has demonstrated increased activities of ALT and AST in the serum after a single dose of SA administration [50]. In addition, Sharma et al. [12], Yousef et al. [14] and Srinivas et al. [53] have reported a similar increase in rats, mice and Labeo rohita fish exposed to SA respectively. Although elevated AST and ALT was observed after SA induced liver damage, we found that plasma AST was decreased in mice fed all the three doses of MRV before SA exposure. A similar decrease in ALT activities was observed in the animals exposed to $\mathrm{SA}$ in combination with 650 or $325 \mathrm{mg} / \mathrm{kg}$ body weight doses of MRV. These results suggest that MRV pretreatment protect the liver against the SA-induced hepatic injury by decreasing or preventing the leakage of $\gamma$-GT, ALP, AST and ALT into circulation.

The result of the liver histopathology complemented that observed for the liver function enzyme markers in the test and control animals. The necrosis and portal inflammation observed in the mice exposed to SA are evidences of direct toxicity of SA to hepatic cells. This is in agreement with the studies of Mandal et al. [54] and Sharma et al. [12] that observed fibrogenesis, karyorrhexis, centrilobular necrosis and cytoplasmic vacuolization in mice and rats exposed to SA. Recently, Das et al. [55] also observed severe necrosis and inflammatory reactions around the liver centrilobular veins of mice administered SA. The 
protective role of the lower doses of MRV against SA induced hepatotoxicity study was confirmed by the result of liver histopathological examination in the present study. Pretreatment of mice with $1300 \mathrm{mg} / \mathrm{kg}$ body weight of the MRV resulted in mild sinusoidal congestion in the liver, while the $650 \mathrm{mg} / \mathrm{kg}$ and 325 $\mathrm{mg} / \mathrm{kg}$ body weight extract of MRV preserved the structural integrity of the liver.

In conclusion our results suggest that pretreatment of mice with methanol extract of Rauvolfia vomitoria especially at low doses may protect cells from SA induced clastogenicity as well as alteration in liver function markers and hepatic injury in mice.

\section{REFERENCE}

[1] National Toxicological Progam. Arsenic and certain arsenic compounds. In: $14^{\text {th }}$ report on carcinogen. Research Triangle Park NC; 2016.

[2] Gambell M, Liu X, Ahsan $\mathrm{H}$, et al. Folate, homocysteine and arsenic metabolism in arsenic exposed individuals in Bangladesh. Env Health Persp 2005; 113: 1683. https://doi.org/10.1289/ehp.8084

[3] Tseng C, Chiou H, Hsueh Y, Chong C, Chen C. Epidemiologic evidence of diabetogenic effect of arsenic. Toxicol Lett 2002; 133: 69-76. https://doi.org/10.1016/S0378-4274(02)00085-1

[4] National research council. Arsenic in drinking water. Washington DC: National Academy Press 1999.

[5] Huff J, Chan P, Nyska A. Is the human carcinogen arsenic carcinogenic in laboratory animal? Toxicol Sci 2002; 5: 1723.

[6] International agency for research on cancer. Some drinking water disinfectants and contaminants, including arsenic. 2004: 84, Lyon.

[7] Vogt B, Rossman, G. Effects of arsenite on p53, p21 and cyclin $D$ expression in normal human fibroblast. A possible mechanism for arsenite's comutagenicity. Mutat Res 2001; 478-159.

https://doi.org/10.1016/S0027-5107(01)00137-3

[8] Lee T, Tanaka P, Lamb T, Gilmer J, Barret, J. Induction of gene amplification by arsenic. Sci 1988; 241: 78-81. https://doi.org/10.1126/science. 3388020

[9] Mead M, Arsenic. In search of an antidote to a global poison. Environ Health Perspect 2005; 13: A378-A386. https://doi.org/10.1289/ehp.113-a378

[10] Vahter M. Interactions between arsenic-induced toxicity and nutrition in early life. J Nutr 2004; 137: 2798-2804. https://doi.org/10.1093/jn/137.12.2798

[11] Ramnathan K, Balakumar B, Panneerselvam C. Effects of ascorbic acid and a-tocopherol on arsenic-induced oxidative stress. Hum Exp Toxicol 2002; 21: 675-680. https://doi.org/10.1191/0960327102ht307oa

[12] Sharma A, Mukesh K, Madhu K. Modulatory role of Emblica officinalis fruit extract against arsenic induced oxidative stress in Swiss albino mice. Chem Biol Interact 2009; 180(1): 20-30.

https://doi.org/10.1016/j.cbi.2009.01.012

[13] Roy M, Sinha D, Sutapa M, Paul S, Bhattacharya R. Protective effect of dietary phytochemicals against arsenite induced genotoxicity in mammalian V79 cells. Indian J Expt Biol 2008; 46: 690-696.
Yousef M, El-Demerdash F, Radwan F. Sodium arsenite induced biochemical perturbations in rats. Ameliorating effect of curcumin. Food Chem Toxicol 2008; 46: 3506-3511. https://doi.org/10.1016/j.fct.2008.08.031

[15] Roychoudhury A, Das T, Sharma A, Taluker G. Dietary garlic extract in modifying clastogenic effects of inorganic arsenic in mice-two generation studies. Mutat Res 1996; 359: 165-170. https://doi.org/10.1016/S0165-1161(96)90263-0

[16] Sofowora A. Medicinal plants and traditional medicine in Africa. Second ed. Ibadan Nigeria. Spectrum Book Ltd: 1993.

[17] Amole O, Yemitan O, Oshikoya K. Anticonvulsant activity of Rauvolfia vomitoria (Afzel). Afr J Pharm Pharmacol 2009; 3(6): 319-322.

[18] Bemis D, Capodice J, Gorroochurn P, Katz A, Buttyan R. Antiprostate cancer activity of a ß-carboline alkaloid enriched extract from Rauwolfia vomitoria. Int J Oncol 2006; 9: 106573.

[19] Akpanabiatu M, Umoh I, Edet E, Ekanem T, Ukaffia S Ndem, J. Effects of interaction of vitamin A and Rauwolfia vomitoria root bark extract on marker enzymes of cardiac diseases. Indian J Clin Biochem 2009; 24(3): 241-244. https://doi.org/10.1007/s12291-009-0045-7

[20] Obembe E, Sokomba S, Olorunfemi O, Alemika T. Antipsychotic effects and tolerance of crude Rauvolfia vomitoria in Nigerian psychiatric in-patients. Phytother Res 1994: 8 (4): 218-223. https://doi.org/10.1002/ptr.2650080406

[21] Waterman. A phytochemist in the African rain forest. Phytochem 1986; 25(1): 3-17. https://doi.org/10.1016/S0031-9422(00)94492-3

[22] Olapade. Clinical evaluation of the potentials of Rauvolfia vomitoria based extract in the treatment of haemorrhoids and anal prolapse in Nigeria. WOCMAP I - Medicinal and Aromatic Plants Conference: part 2 of 4 . ISHS Acta Horticulturae 1992; 332.

[23] Burkill. Useful plants of West Tropical Africa. Vol 2. Families E-I: Royal Botanical Gardens; Kew 1994.

[24] Principe $P$. The economic significance of plants and their constituents as drugs. In: Wagner $\mathrm{H}$, Hikino $\mathrm{H}$, Farnsworth $\mathrm{NR}$, editors. Economic and medicinal research. Vol. 3. London: Academic Press 1989; pp. 1-17. https://doi.org/10.1016/B978-0-12-730064-1.50005-7

[25] Amole O, Onabanjo A, Odofin A. The analgesic effect of Rauvolfia vomitoria (Afzel). Biomed Res 2006; 17 (2): 12527.

[26] Amole O, Agbaje E, Onabanjo A. Chemotherapeutic actions of Rauvolfia vomitoria on Plasmodium yoelii infection. Nig $J$ Physiol Sci 1993; 9: 35-38.

[27] Schmid W. The micronucleus test. Mutat Res 1975; 31: 9-15. https://doi.org/10.1016/0165-1161(75)90058-8

[28] Adler I. Cytogenic tests in mammalian. In: Venitt S, Paarry $\mathrm{JM}$, editors. Mutagenicity testing-A practical approach. Oxford Washington DC: IRL Press 1984; p. 275-306.

[29] Szasz. A kinetic photometric method for serum gamma glutamyl transferase. Clin Chem 1969; 124: 124-36.

[30] Geranó M, Angelo D, Sanogo R, Morabito A, Pergolizzi S, De Pasquale R. Hepatoprotective activity of Trichilia roka on carbon tetrachloride-induced liver damage in rats. JPP 2001; 53: $1569-74$. https://doi.org/10.1211/0022357011777954

[31] Hayash $\mathrm{M}$. The micronucleus test-most widely used in vivo genotoxicity test-Genes and Environment 2016; 38: 18. https://doi.org/10.1186/s41021-016-0044-x

[32] Odunola O, Uka E, Akinwumi K, Gbadegesin M, Osifeso O, Ibegbu M. Exposure of laboratory mice to domestic cooking gas. Implications for toxicity. Int J Environ Res Public Health 2008; 5(3): 172-176

https://doi.org/10.3390/ijerph5030172 
[33] Balakumar B, Suresh R, Venugopal R. Modulatory effects of ascorbic acid and $\alpha$ - tocopherol on arsenic induced micronuclei formation. Int J Pharmacol 2010; 6 (5): 676-680. https://doi.org/10.3923/iip.2010.676.680

[34] Gurr J, Liu F, Lynn S, Jan K. Calcium-dependent nitric oxide production is involved in arsenite induced micronulei. Mutat Res 1998; 416: 137-148. https://doi.org/10.1016/S1383-5718(98)00076-X

[35] Ahmad S, Kitchin K, Cullen W. Plasmid DNA caused by methylated arsenicals, ascorbic acid and human ferritin. Toxicol Lett 2002; 133: 47-57. https://doi.org/10.1016/S0378-4274(02)00079-6

[36] Mass M, Tennant A, Roop B, et al. Methylated trivalent arsenic species are genotoxic. Chem Res Toxicol 2001; 14: 355- 361. https://doi.org/10.1021/tx000251/

[37] Shi $\mathrm{H}$, Shi X, Liu K. Oxidative mechanism of arsenic toxicity and carcinogenesis. Mol Cell Biochem 2004; 255: 67-78. https://doi.org/10.1023/B:MCBI.0000007262.26044.e8

[38] Wiseman. Damage to DNA by reactive oxygen and nitrogen species. Role in inflammatory disease and progression to cancer. Biochem J 1996; 313: 17-29. https://doi.org/10.1042/bj3130017

[39] Yamanaka K, Okada S. Induction of lung-specific DNA damage by metabolically methylated arsenics via the production of free radicals. Environ Health Perspect 1994; 102(Suppl 3): S37-40. https://doi.org/10.1289/ehp.94102s337

[40] Kato K, Hayashi $H$, Hasegawa A. DNA damage induced in cultured human alveolar (L-32) cells by exposure to dimethylarsinic acid. Environ Health Perspect 1994; 102: 285-288. https://doi.org/10.1289/ehp.94102s3285

[41] Eastmond D, Tucker J. Identification of aneuploidy inducing agents using cytokinesis blocked human lymphocytes and antikinetochore antibody. Environ Mol 1989; 13: 34-43. https://doi.org/10.1002/em.2850130104

[42] Gudi R, Sandhu S, Athwal S. Kinetochore identification in micronuclei in mouse bone marrow erythrocytes. An assay for detection of aneuploidy inducing agent. Mutat Res 1990; 234: 263-268. https://doi.org/10.1016/0165-1161(90)90038-P

[43] $\mathrm{Yu}$ J, Ma Y, Drisko J, Chen Q. Antitumor activities of Rauwolfia vomitoria extract and potentiation of carboplatin effects against ovarian cancer. Curr Therapeu Res 2013; 75: 8-14. https://doi.org/10.1016/j.curtheres.2013.04.001

[44] Yondo J, Fomekong G, Komtangui M. In vitro antioxidant potential and phytochemical constituents of three
Cameroonian medicinal plants used to manage parasitic diseases. Pharmacology Online 2006; 1: 648-657.

[45] Beljanski M. Three alkaloids as selective destroyers of cancer cells in mice. Synergy with classic anticancer drugs. Oncol 1986; 43: 198-203.

https://doi.org/10.1159/000226363

[46] Kim D, You K, Liu M. GADD153-mediated anticancer effects of $\mathrm{N}$-(4-hydroxyphenyl) retinamide on human hepatoma cell. J Biol Chem 2002; 277: 38930-38938. https://doi.org/10.1074/jbc.M205941200

[47] Luethy J, Holbrook N. Activation of the gadd153 promoter by genotoxic agents. A rapid and specific response to DNA damage. Cancer Res 1992; 5: 5-10.

[48] Karmaker R, Banerjee A, Datta S, Chatterjee M. Influence of cadmium intoxification on hepatic lipid peroxidation, glutathione level and glutathione-S-transferase and gammaglutamyl transpeptidase activities. Correlation with chromosome aberration in bone marrow cells. J Environ Pathol Toxicol Oncol 1999; 18: 277-287.

[49] Lee $D$, Blomhoff $R$, Jacobs $D$. Is serum gamma glutamyl transferase a marker of oxidative stress? Free Radic Res 2004; 38: 535-539. https://doi.org/10.1080/10715760410001694026

[50] Odunola O, Akinwumi K, Ogunbiyi B, Tugbobo O. Interaction and enhancement of the toxic effects of sodium arsenite and lead acetate in wistar rats. Afr J Biomed Res 2007; 10: 5965

[51] Jayakumar T, Ramesh E, Geraldine P. Antioxidant activity of the oyster mushroom Pleurotus ostreatus on $\mathrm{CCl}$-induced liver injury in rats. Food Chem Toxicol 2006; 44: 1989-96. https://doi.org/10.1016/j.fct.2006.06.025

[52] Gaskill C, Miller L, Mattoon J, et al. A. Liver histopathology and liver serum alanine aminotransferase and akaline phosphatase activities in epileptic dogs receiving phenobarbital. Vet Pathol 2005; 42: 147-160. https://doi.org/10.1354/vp.42-2-147

[53] Srinivas S, Prabhath N, Raghavender M, Yerramill A. Effect of arsenic and chromium on the serum amino-transferases activity in Indian Major Carp Labeo rohita. Int J Environ Res Public Health 2007; 4(3): 224-227. https://doi.org/10.3390/ijerph2007030005

[54] Mandal C, Das S, Basu M, Rohini N, Nirmalendu D. Hepatoprotective activity of liposomal flavonoid against arsenite-induced liver fibrosis. JPET 2007; 320: 994-1001 https://doi.org/10.1124/jpet.106.114215

[55] Das AK, Sujit B, Ranabir S, et al. Protective effect of Corchorus olitorius leaves on sodium arsenite-induced toxicity in experimental rats. Food Chem Toxicol 2010; 48: 326-335. https://doi.org/10.1016/j.fct.2009.10.020 